lowest flowers of the inflorescence are female, and seated in the axils of the sheathing leaves; but the style is enormously elongated so as to carry the stigma to the surface of the water for fertilisation. This recall; the habit of Vallisneria. But, as Mr. Bentham reminds us, the resemblances of Hydrocharidece and of Naiadacece are essentially adaptive, and must not blind us to the real profoundly divergent affinity.

It is worth noting, as a hint to those interested in researches of this fascinating kind, that the investigations of Dr. Hieronymus were made partly on material preserved in a mixture of two-thirds alcohol and one-third glycerine, partly in an aqueous solution of salicylic acid (no further details are given).

W. T. T. D.

\section{PROFESSOR FLOWER}

PROFESSOR FLOWER'S resi'nation of the office of Conservator of the Museum of the Royal College of Surgeons was received at the last meeting of the Council of that body, held on March I3, whereupon it was moved by Sir James Paget, seconded by Mr. Erichsen, and resolved unanimously:- "That the Council hereby desire to express to Mr. William Henry Flower their deep regret at his resignation of the office of Conservator of the Museum of the College.

"That they thank him for the admirable care, judgment, and zeal with which for twenty-two years he has fulfilled the various and responsible duties of that office.

"That they are glad to acknowledge that the great increase of the Museum during those years has been very largely due to his exertions and to the influence which he has exercised, not only on all who have worked with him, but amongst all who have been desirous to promote the progress of anatomical science.

"That they know that, whilst he has increased the value and utility of the Museum by enlarging it, by preserving it in perfect order, and by facilitating the study of its contents, he has also maintained the scientific repute of the College by the numerous works which have gained for him a distinguished position amongst the naturalists and biologists of the present time.

"And that, in thus placing on record their high appreciation of the services of Mr. Flower, the Council feel sure that they are expressing the opinion of all the Fellows and Members of the College, and that they will all unite with them in wishing him complete success and happiness in the i:nportant office to which he has been elected."

The conditions under which the Conservatorship of the Museum of the College will be held in future are at present under discussion, and will probably be decided at the next meeting of the Council on the Ioth inst., when the office will be declared vacant, and candidates invited to send in their applications.

\section{THE DEEP-SEA DREDGINGS OF THE

$$
\text { "TALISMAN"-CRUSTACEA }
$$

$\mathrm{I}$ a previous article attention was called to some of the more remarkable of the deep-sea fishes taken during the recent cruise of the French frigate the Talisman: not less interesting were the numerous forms of Crustacea dredged during the same cruise, a fine collection of which were also on view at the Jardin des Plantes, Paris, as part of the spoils brought home after the voyage. From a survey of the specimens it is evident that these Crustacea are to be found at all depths of the ocean : some pass their lives floating on its surface, feeding thereon or amid the acres of Sargassum weed; while others live at depths of from 4000 to 5000 metres. The so-called swimming crabs which form a section of the Brachyura would seem to be extremely rare at great depths. Certain species taken during the Talisman's cruise are remarkable for their very extensi ve geographical distribution; thus, species of Batynectes which were found at depths of from 450 to 950 metres off the coasts of Morocco and about the Cape Verd Islands, seemed very closely related to the swimming crabs (Portunus) of our own seas, and again to be very nearly connected to species of the same genus collected at the Antilles, in the Mediterranean, and in the Arctic Ocean. Another section of the Brachyura, with sharp triangular bodies (Oxyrrhyncha), contains species which are to be met with at much greater depths; thus Lispognatus thompsoni (A. M. Edw.) was dretged off the coasts of Morocco from depths of between 600 and 1500 metres, and Scyramathia carpenteri was taken at the same place from a depth of I 200 metres. The former of these species has been found in the North Sea, and the latter has been taken off the north of Scotland and in the Mediterranean. The Crustacea intermediate by their forms between the Bracbyura and the Macrura were found in abundance at very great depths, and the forms found see ned in great measure to belong to "transition" forms; so one was often surprised to find a form, which taken by itself appeared abundantly distinct, quite connected with others by numerous intermediary forms. Thus species of Ethusa, Dorippe, Homola, and Dromia seem to present such numerous shades of gradation as to perplex one completely in the difficult task of classifying these genera. Some of these forms are also very remarkable for their geographical distribution: a species of Dicranomia, described by Milne-Edwards from the Antilles, was found off Morocco, and Homola cuvierii, up to this thought to be peculiar to the Mediterranean, was found at the Azores and the Canaries. But the most remarkable instance of the geographical extension of which some genera are capable is furnished by some species of the family Lithodina. These Crustacea to this have been known as inbabitants of the Arctic and Antarctic regions, living in the littoral zone, but now they have been found under the tropics the only difference being that in this latter locality they have contrived to find congenial conditions of life by abandoning their shallow-water life and betaking themselves to the cool depths of over 1000 metres. A fact like this is not without its interest, inasmuch as it shows how some forms can spread themselves from the frozen seas of the north to the seas of the tropics, and so from the region of one Pole to the other; altering their conditions of life as necessity demanded, and resuming thei. old habits when the opportunity to do so again o:curred.

The Crustacea known as Hermit Crabs were found to extend to a depth of 5000 metres; as is well known, the terminal portions of the bodies of these Hermits are soft, not covered like the head and claws of the crab with a strong calcareous shell, and these animals have the habit of tucking the soft part of their bodies for security into the body-whorl of some empty shell; but at the great depths referred to shells suitable for this purpose are not to be found, and the hermit crabs inhabiting these depths must often be in great difficulties for material wherewith to cover themselves. In one specimen taken off Morocco this covering consisted of a living colony of a very pretty species of Epizoanthus.

Species of the family Galatheidea were found in profusion at all depths ; but the colour of their body, generally that of a red or pink hue, was in the forms from the great depths of a uniform white. Some species were found which occupied the interior of those lovely siliceous sponges belonging to the geius Aphrocallistes. One new species, Galathodes antonii, was found at a depth of 4000 metres, and anotlier, from the same depth, with its abdomen coiled twice upon itself, has been also described by A. M. Edwards as new (Ptychogaster formosius).

Of the group of Eryonidæ a considerable number of both genera and species were dredged. Of these, those 
belonging to the genera Polycheles, Wilmoesia, were from depths of from 4000 to 5000 metres, and the wonderful transparency of the forms permitted the whole internal viscera to be distinctly seen. Some species of Pentacheles were evidently allied to the fosil forms of Eryon.

Of the Crustacea belonging to the group of Macrura, the one to which the crayfish and shrimps belong, many were taken at very great depths. Off the Cape Verd Islands, from a depth of 500 metres, a thousand individuals of a new species of Pandalus were taken. Among the most remarkable of all of these forms is the one which, through the courtesy of the editor of $L a$ Nature, from which journal this notice is in part translated, we are enabled to give the accompanying illustration. Named Nematocarcinus gracilipes by Alphonse

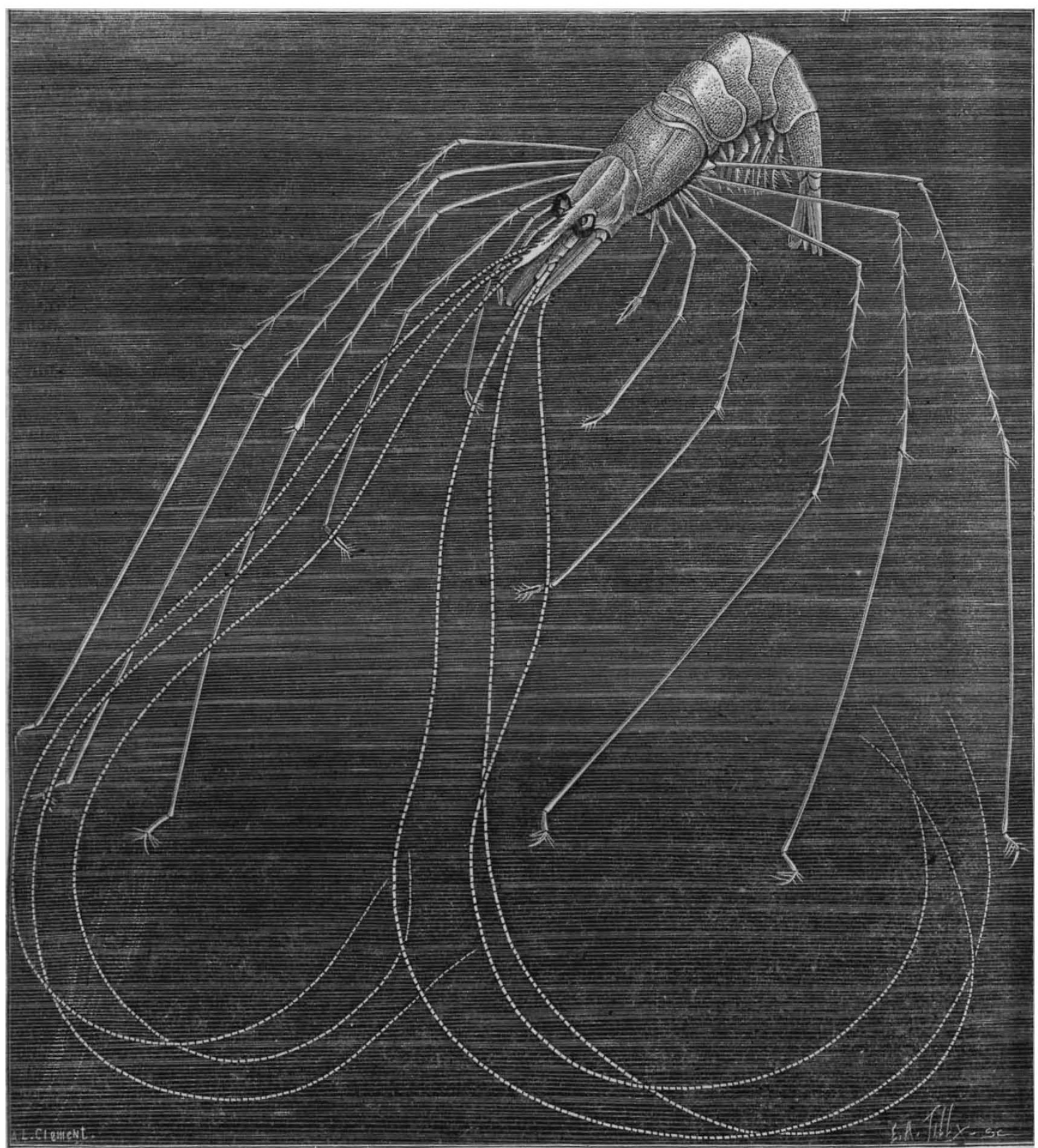

Nematocarcinus gracilipes (A. M. Edw.).

Milne-Edwards, it was, when taken fresh from a depth of 850 metres, of a splendid rose colour. The extreme length of its antennæ will at once attract attention, and tno less remarkable are the wonderfully attenuated feet, of which the third, fourth, and fifth pairs are longer than the first and second. The eyes are large, but the eyestalks are not elongated. In another member of this group, Clyphus marsupialis, the female had the Jateral portions of the abdominal segments developed so as to form a pouch-like receptacle, in which the eggs were deposited.

When trying to draw conclusions from the phenomena presented by the numerous forms of Crustacea collected during the Talisman cruise, one is struck by the strange diversity in these phenomena. While some of the species are blind, others have well-developed organs of vision; while in some the fye-stalks are fexible, in others they 
are immovable; while in some there is a very marked transparency of the integuments and a decided softness of the muscular tissues, in others neither of these facts is at all apparent. Some of the deep-sea Crustacea are beautifully phosphorescent, and in certain species this phosphorescence is not diffused but is limited to some special areas of their bodies, and in a new species, Acantephyra pellucida (A. M. Edw.), the feet are adorned with phosphorescent bands. We of necessity know so little of the habits of these new, strange forms, that it would be premature to draw scientific conclusions from their structure.

\section{THE SOCIETY FOR THE BIOLOGICAL INVES-} TIGATION OF THE BRITISH COASTS

$T \mathrm{HE}$ meeting which we previously announced as about to be held for the purpose of inaugurating a new society baving the above title, took place last Monday in the rooms of the Royal Society, Prof. Huxley being in the chair. The meeting was large and influential. Among those present were the Duke of Argyll, the Earl of Dalhousie, Lord Arthur Russell, Sir Lyon Playfair, M.P., Dr. W. B. Carpenter, Sir Joseph Hooker, the Hon. Edward Marjoribanks, M.P., Sir John Lubbock, M.P., President of the Linnean Society, Mr. J. Blake, M.P., Sir George Nares, Dr. John Rae. Sir Joseph Fayrer, Capt. Verney, R.N., Prof. Flower, Prof. Ewart, Dr. John Evans, Prof. Bonney, Dr. Spencer Cobbold, Mr. John Murray (of the Challenger Office), Dr. J. Gwyn Jeffreys, Dr. Günther, Prof. Moseley, Mr. G. J. Romanes, Mr. H. C. Sorby, Mr. Francis Galton, Mr. Brady, Prof Crofton, Mr. Dawson Williams, Prof. St. George Mivart, Mr. Busk, Dr. Sclater, Dr. Dodson (Netley), Mr. Thiselton Dyer, Mr. H. C. Burdett, Prof. Donkin, Dr. John Murie, librarian of the Linnean Society, Mr. W. H. Dallinger, Dr. A. Geikie, Mr. E. Forbes Lankester, Mr. Saville Kent, Mr. M'Lachlan, Dr. Herbert Carpenter (of Eton), Prof. Jeffrey Bell, Mr. Frank Crisp, and Prof. Ray Lankester. Letters regretting inability to attend were read from Lord Derby, the Marquis of Hamilton, Sir Thomas Dakin, Mr. Chamberlain, Mr. Burdett-Coutts, Mr. R. W. Duff, M.P., and Dr. Dohrn.

Prof. Huxley, in opening the proceedings, began by observing that the object with which the meeting had to deal was not in his hands, but in those of Prof. Lankester, who had requested that the Royal Society should foster an undertaking which promised well for the progress of science. The establishment of marine biological stations had been undertaken during the last few years by most of the civilised countries, and was, indeed, a necessary result of the great change which had taken place in the aims of biological science. The study of development began about half a century ago, and the ramifications of that inquiry, which had been extended to the mode of becoming of all live things by Mr. Darwin, had caused a complete change in the methods of biological research. In order to investigate the living being it was now no longer deemed sufficient, as in the days of our great-grandfathers, to observe its outside, or even, in the days of our grandfathers, to examine its anatomy. We have now to trace its developmental growth from the egg, and we are able to do so with a thoroughness of which no one in his young days could have had any conception. Such was one good reason for founding an institution of this kind from a purely scientific point of view. But there was another reason from another point of view which was practical. We had great fisheries and great fishery interests, and up to within the last thirty years legislation with reference to them was almost entirely haphazard, owing to our ignorance of the habits, modes of life, reproduction, and so on, of marine animals which were economically useful. If we are to have any considerable improvement in our legislation in this respect, our arguments and reasonings with a view to it must rest upon sound and exact observation. In conclusion, he wished to say with special emphasis that there was no possibility of any rivalry between the society which it was now proposed to found and another society the formation of which was announced a few days ago by H.R.H. the Prince of Wales. That society was, in the ordinary sense of the word, practical. He trusted that when both societies were established, so far from there being any conflict between their aims, they would work in concurrence to a common end.

The Duke of Argyll said the resolution which had been placed in his hands was-." That in the opinion of this meeting there is an urgent want of one or more laboratories on the British coast, similar to those existing in France, Austria, Italy, and America, where accurate researches may be carried on, leading to the improvement of zoological and botanical science, and to an increase in our knowledge as regards the food, life, conditions, and habits of British food fishes and mollusks in particular, and the animal and vegetable resources of the sea in general." The fact of their being called together to form a voluntary society to carry out these objects implied a discovery on the part of those who had taken a leading part in this matter that the work was not likely to be taken up by the Government. He was afraid that in this respect the British Government had always stood rather behind those of other countries, whether monarchical or republican. There were other agencies by which facts about food fishes would be obtained, and he instanced the researcbes of the President of the Royal Society, and a valuable paper recently contributed by Prof. Ewart upon one of the most important questions connected with food fishes-the spawning of the herring. When further researches of this kind should be forthcoming, it can scarcely admit of doubt that, by making us acquainted with the life-history and habits of the berring, they will serve to improve the herring fisheries. He had himself good reason to appreciate the importance of acquiring information of this kind, for in the vicinity of his own residence the fishing community was suffering distress on account of the herring having abandoned Loch Fyne without any one being able, in the present state of our knowledge, to assign the cause. Moreover, the opposition which was raised to ground-trawling in Loch Fyne, on the supposition that the practice is destructive of herring spawn, has been shown by such researches to be without any justification-the spawn having been found to adhere closely to the sea-bottom. But great as would be the probable economic nature of a marine biological station in the improvement of our fisheries, he thought that the chief object in promoting this society should be that of promoting the interests of biological science. Enlarging upon the importance of this science, he concluded by observing that the branches of it which would fall to the lot of this society to cultivate would have the advantage of avoiding contact with the question of vivisection; for he supposed that even the most susceptible of antivivisectionists would scarcely have their feelings touched by physiological experiments on jelly-fish.

Sir Lyon Playfair, M.P., in seconding the resolution, dwelt upon the anomaly that a country which depends so much upon its fisheries as Great Britain should hitherto have been the only Great Power which had not founded a zoological station. He then proceeded to enumerate some of the economic advantages which had been secured by such institutions elsewhere, especially in America.

Lord Dalhousie and Prof. Flower also supported the motion.

Dr. W. B. Carpenter moved :- "That it is desirable to found a society, having for its object the establishment and maintenance of at least one such laboratory at a suitable point on the coast, the resources of the laboratory 